OPEN ACCESS

Edited by:

Mario Barletta,

Universidade Federal de Pernambuco

(UFPE), Brazil

Reviewed by:

Victor Enrique Cussac,

Centro Científico Tecnológico CONICET Patagonia Norte, Argentina José Lino Vieira De Oliveira Costa,

Universidade de Lisboa, Portugal

*Correspondence:

Nelson Ferreira Fontoura

nfontoura@pucrs.br

Specialty section: This article was submitted to Marine Ecosystem Ecology, a section of the journal Frontiers in Marine Science

Received: 30 July 2018 Accepted: 23 January 2019 Published: 12 February 2019

Citation: Fontoura NF, Schulz UH, Alves TP,

Silveira TCL, Pereira JJ and

Antonetti DA (2019) How Far

Upstream: A Review of Estuary-Fresh Water Fish Movements in a Large

Neotropical Basin.

Front. Mar. Sci. 6:39.

doi: 10.3389/fmars.2019.00039

\section{How Far Upstream: A Review of Estuary-Fresh Water Fish Movements in a Large Neotropical Basin}

\author{
Nelson Ferreira Fontoura ${ }^{1 *}$, Uwe Horst Schulz ${ }^{2}$, Thaís Paz Alves ${ }^{1}$, \\ Thiago Cesar Lima Silveira ${ }^{3}$, Joana Jordão Pereira ${ }^{1}$ and Débora Alessandra Antonetti ${ }^{1}$ \\ ${ }^{1}$ Laboratório de Ecologia Aquática, Escola de Ciências and Instituto do Meio Ambiente, Pontifícia Universidade Católica do \\ Rio Grande do Sul, Porto Alegre, Brazil, ${ }^{2}$ Laboratório de Ecologia de Peixes, Escola Politécnica, Universidade do Vale do Rio \\ dos Sinos, São Leopoldo, Brazil, ${ }^{3}$ Departamento de Ecologia e Zoologia, Universidade Federal de Santa Catarina, \\ Florianópolis, Brazil
}

The present study comprises the first systematic analysis of the limits of upstream movement by some fish species that use the estuarine area of the Patos Lagoon basin in southern Brazil. The Sinos River sampling program included 86 sites, sampled from 1998 to 2014, covering lowland stretches and headwater streams. The Guaíba sampling program was conducted from February 2011 to March 2013 and comprised 59 independent samples. Six fish species using estuarine areas occur in the upper Patos basin, 250-500 km from the Patos Lagoon outlet to the Atlantic Ocean. Parapimelodus nigribarbis specimens ranged from 11.3 to $18.9 \mathrm{~cm}$ (median $=13.3 \mathrm{~cm}$ ) in length, i.e., were adults (Sinos, $n=459$; Guaíba, $n=149$ ). The species was captured almost $500 \mathrm{~km}$ from the Patos outlet, as far as $180 \mathrm{~km}$ upstream in the Sinos main channel. In Guaíba Lake, the species was captured mainly in autumn, although it was more abundant in winter and spring in the Sinos River. Lycengraulis grossidens was captured in the Sinos Basin, restricted to the lower stretches in spring and summer months ( $n=7)$. In Guaíba Lake $(n=134)$ the species occurred throughout the lake and year-round, and was ten times more abundant in spring. Most specimens were adult $(8.2-26.9 \mathrm{~cm}$, median $=20.0 \mathrm{~cm})$. Most Micropogonias furnieri individuals $(n=63)$ were juveniles $(10.7-33.4 \mathrm{~cm}$, median $=14.2 \mathrm{~cm})$. The species was not captured in the Sinos Basin. In Guaíba Lake M. furnieri occurred predominantly in the southernmost part (downstream) and was more abundant $(>10 x)$ in winter. Genidens genidens $(n=27)$ was captured only in summer in the southern part of Guaíba Lake (closest to the outlet). Most individuals were adults $(24.5-34.0 \mathrm{~cm}$, median $=27.8 \mathrm{~cm})$. Genidens barbus $(n=7)$ was restricted to spring and summer months and was captured only in southern (near-outlet) parts of Guaíba Lake, comprising mainly large juveniles and adults $(31.5-68.0 \mathrm{~cm}$, median $=37.9)$. Mugil liza $(n=13)$ appeared in spring in relatively low abundances but was widespread throughout Guaíba Lake during the summer. The 
species was not captured in the Sinos sampling program. The size profile comprised specimens nearing maturity $(34.3-45.5 \mathrm{~cm}$, median $=38.9 \mathrm{~cm})$. Finally, we suggest possible biological cycles for these species that combine these new distribution data with published information.

Keywords: estuarine fish, ecosystem connectivity, amphidromous, anadromous, catadromous, potadromous

\section{INTRODUCTION}

The study of fish migration patterns, due to their complexity, has been a challenge for centuries. Difficult to follow, fish can move among marine areas, estuaries and fresh waters to reproduce, locate nursery grounds or feed. These migrations, which may include entire populations or only parts of them, can transfer huge amounts of biomass and energy between ecosystems, and have important ecological, economic and social implications (Chapman et al., 2012b; Metcalfe and Craig, 2012).

The coastal landscape of southern Brazil is an interesting example. As a consequence of disrupted research programs, a full understanding of the biological cycles of migratory fish along the Patos Lagoon system suffers from several lacunae, especially concerning the upstream distribution limits and seasonal movement cycles of migratory species. The present study analyzed the distribution patterns of six fish species, from the upper Patos Basin (Guaíba Lake and Sinos Basin) to the Patos Lagoon outlet to the Atlantic Ocean, covering distances of 250-500 km: Lycengraulis grossidens (Engraulididae), Mugil liza (Mugilidae), Micropogonias furnieri (Sciaenidae), Parapimelodus nigribarbis (Pimelodidae), Genidens genidens and Genidens barbus (Aridae).

The Atlantic sabretooth anchovy L. grossidens occurs from Belize to southern Argentina (Golfo San Matías; Mai and Vieira, 2013). The species is eurytopic, with records from fresh waters to the coastal shelf (Whitehead et al., 1988; Barletta et al., 2010), and can reproduce in both fresh and brackish water (Mai and Vieira, 2013). Reproduction is reported for spring and summer months in the southern part of its range. L. grossidens has been classified as a freshwater resident, anadromous, marine migrant, estuarine resident, catadromous, or semi-catadromous (see Mai and Vieira, 2013 for review) and most recently as facultatively amphidromous (Mai et al., 2014).

The gray mullet $M$. liza is a typical catadromous fish, widely distributed along the western Atlantic coast of South America (Menezes et al., 2010). Its life cycle comprises reproductive migrations each autumn from Argentina and southern Brazil, to spawn between northern Santa Catarina and Paraná (Lemos et al., 2014). Along the species' distribution range, the Patos Lagoon is the main nursery habitat and an inland fishery ground (Vieira, 1991; Vieira and Scalabrin, 1991; Lemos et al., 2014).

The whitemouth croaker $M$. furnieri occurs in the western Atlantic Ocean, from the Caribbean Sea to the northern Argentine coast (Isaac, 1988). In southern Brazil, this croaker can be found from the marine surf zone and continental shelf to the upper (freshwater) zone of the Patos Lagoon, with a springsummer migration to reproduce in brackish waters (Muelbert and Weiss, 1991), using estuaries as nursery grounds (Costa et al., 2014) in a pattern of anadromy.

The mandí catfish $P$. nigribarbis is restricted to the Patos Lagoon basin (Lucena et al., 1992) and is recorded year-round in the estuarine (Vieira and Castello, 1997; Garcia et al., 2003) and freshwater areas of Patos Lagoon (Bertaco and Becker, 2000). The species shows higher gonadosomatic indexes (GSI) in spring and summer (Fontoura et al., 2018). Based on monthly samples with gill nets and beach seines in limnetic zones, Bertaco and Becker (2000) identified that the species was more abundant in spring and summer, proposing a seasonal species movement from nearshore to deeper water in Guaíba Lake, with the fish occupying nearshore areas in spring and summer and deeper water in autumn and winter (potamodromy; Chapman et al., 2012b). Garcia et al. (2003), sampling with beach seines, also inferred an increased abundance in spring and summer in the Patos estuary. Nevertheless, the presence of larvae recorded for estuarine areas (Muelbert and Weiss, 1991) and the upstream seasonal cycles of abundance also suggests possible semi-anadromy (sensu Chapman et al., 2012b).

The white sea catfish G. barbus occurs on the coasts and estuaries of South America, from Bahia in northeastern Brazil to San Blás on the central Argentine coast (Velasco et al., 2007). The life cycle of the species has been described for the Patos Lagoon (Reis, 1986; Haimovici, 1997). This catfish migrates from coastal waters to estuarine areas at the end of winter for reproduction, seeking oligohaline waters for spawning (anadromy). The males mouth-breed the eggs and juveniles for about 2 months. From December on, catches in the estuaries rapidly decrease, suggesting a return to coastal waters.

The guri sea catfish G. genidens ranges from Ceará in northeastern Brazil to the central Atlantic coast of Argentina (Acero and Bentancur, 2010). The species' life cycle in Patos Lagoon is poorly known but may be similar to that of G. barbus.

The present study aimed to contribute to the understanding of the biological cycles of $L$. grossidens, M. liza, M. furnieri, P. nigribarbis, G. genidens and G. barbus. We present the first systematic records of upstream distribution limits for these fish species using the Patos Lagoon estuary, combining new data with available information to describe consensus information and aspects that are still in need of attention.

\section{MATERIALS AND METHODS}

The Patos Lagoon ( $<8 \mathrm{~m}$ deep) is $250 \mathrm{~km}$ long and $60 \mathrm{~km}$ wide $\left(\sim 10,000 \mathrm{~km}^{2}\right)$, dominated by fresh to oligohaline waters (Figure 1). The estuarine area is generally limited to the 


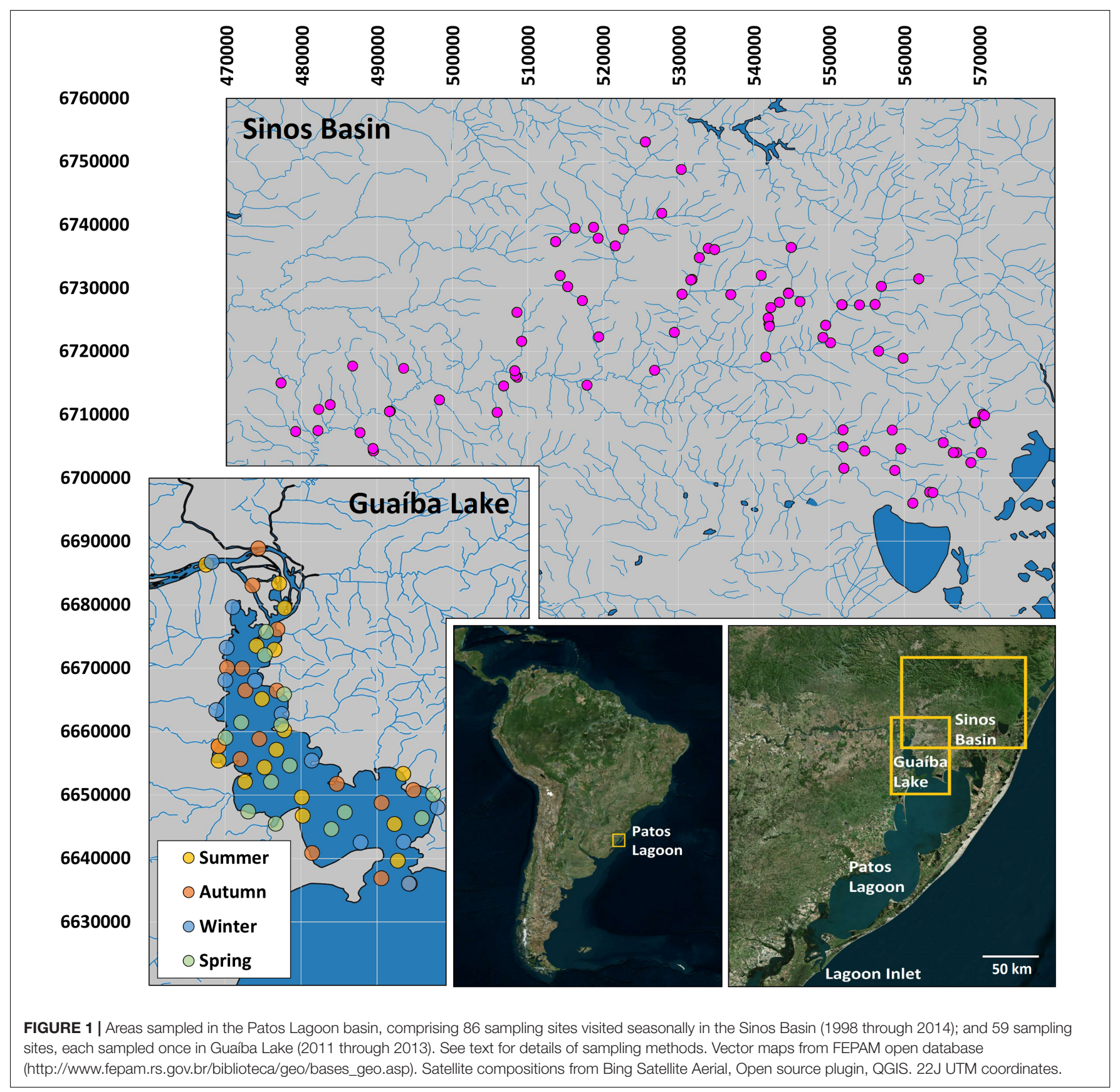

southern $10 \%$, although the upper limit of the saline waters shifts seasonally. Guaíba Lake on the northwestern edge of the Patos Lagoon is $50 \mathrm{~km}$ long and $19 \mathrm{~km}$ wide $\left(\sim 500 \mathrm{~km}^{2}\right)$, and most of the lake is shallower than $3 \mathrm{~m}$. A deltaic system on its northwestern upstream border is formed by incoming rivers (Jacuí, Caí, Sinos and Gravataí). The Sinos River basin, $210 \mathrm{~km}$ long and up to $600 \mathrm{~m}$ a.s.l., is a small part of the area where fish move to and from the Patos Lagoon estuary. The artisanal fishery, organic pollution and other widespread environmental impacts of a large metropolitan area (over 4 million inhabitants) are the main pressures on the fish populations. A general overview and assessment of the conservation status of the Patos Lagoon system were provided by Fontoura et al. (2016).

The Sinos River sampling program comprised 86 sites that were sampled monthly during several projects from 1998 through 2014, extending from lowland stretches to the headwaters (Figure 1). In the Sinos River main channel, fish were captured by 1 -h electrofishing by boat and a $7.5 \mathrm{~kW}(750 \mathrm{~V})$ unpulsed direct-current generator along both banks, and with a set of 7 gill nets set out for approximately $16 \mathrm{~h}$ from early afternoon to the next morning (all nets were $20 \mathrm{~m}$ long with mesh sizes 15, 20, $25,30,35,40$, and $50 \mathrm{~mm}$, adjacent knots; the $15-25 \mathrm{~mm}$ gillnets measured $1.5 \mathrm{~m}$ high and the $30-50 \mathrm{~mm}$ gillnets were $2.0 \mathrm{~m}$ high). 
In the smaller tributaries, fish were captured by 1-h electrofishing (2 kW, $750 \mathrm{~V}$, unpulsed direct current).

The Guaíba sampling program extended from February 2011 to March 2013 and comprised 59 sampling sites, each sampled only once. Although samples were not replicated at the same site along Guaíba Lake, the sampling program was designed to allow wide sampling coverage, comprising combinations in space (upstream, downstream, shallow and deep water) and time (year, season) (Figure 1). Fish were captured using surface and bottom gillnets (60 m long), each comprising a set of 12 different mesh sizes (5-m panels, $1.5 \mathrm{~m}$ high, mesh sizes of 15, 20, 25, 30, 35, 40, $45,50,55,60,65$, and $70 \mathrm{~mm}$, adjacent knots). Fishing time was approximately $20 \mathrm{~h}$, from early afternoon to the next morning. Fish from the Guaíba sampling program were measured (total length) to the nearest millimeter. Additional distribution records were obtained from public databases of museum records ${ }^{1}$.

\section{RESULTS}

Six fish species recorded for the estuarine area of the Patos Basin are also present in the limnetic areas sampled (Guaíba Lake and the Sinos River Basin), over distances of 250-500 km from the Patos Lagoon outlet to the Atlantic Ocean: L. grossidens (Engraulidae), M. liza (Mugilidae), M. furnieri (Sciaenidae), P. nigribarbis (Pimelodidae), G. genidens and G. barbus (Aridae). Of these, only P. nigribarbis and L. grossidens were captured in the Sinos Basin (Figure 2). Information on fish size profiles is available for the Guaíba Lake samples (Figure 3), where all the species were detected.

The mandí catfish $P$. nigribarbis had the widest distributional range, up to almost $500 \mathrm{~km}$ from the Patos outlet, $180 \mathrm{~km}$ upstream in the Sinos River basin ( $n=459$, Figure 2$)$. In the Sinos River main channel, this catfish was present year-round, in higher abundance $(>10 \times)$ in winter and spring. In Guaíba Lake $(n=149)$, the species was captured in autumn in deeper water, except for a few specimens collected in summer (Figure 4). The size profile of $P$. nigribarbis included fish in the range of 11.3 to $18.9 \mathrm{~cm}$ (median $=13.3 \mathrm{~cm})$, i.e., adults. Museum records extend as far as $588 \mathrm{~km}$ upstream (from the Patos outlet to the Atlantic Ocean) in the Taquari Basin (Museu de Ciências e Tecnologia da PUCRS, MCT 38912) or $694 \mathrm{~km}$ in the upper Jacuí River (Museu de Ciências e Tecnologia da PUCRS, MCT 23770).

In the Sinos River Basin, the Atlantic sabretooth anchovy L. grossidens was limited to the lower stretches in spring and summer months, in relatively low abundances $(n=7)$. In Guaíba Lake, L. grossidens occurred throughout the lake and year-round, although it was tenfold more abundant in spring $(n=134$, Figure 5). The size profile comprised mainly adult specimens $(8.2-26.9 \mathrm{~cm}$, median $=20.0 \mathrm{~cm})$. Museum records extend as far as $400 \mathrm{~km}$ upstream (from the Patos outlet to the Atlantic Ocean) in the Taquari Basin (Museu de Ciências e Tecnologia da PUCRS, MCP 19468).

Mainly juveniles of the whitemouth croaker $M$. furnieri were captured $(10.7-33.4 \mathrm{~cm}$, median $=14.2 \mathrm{~cm})$. Croakers were

${ }^{1}$ www.splink.org.br
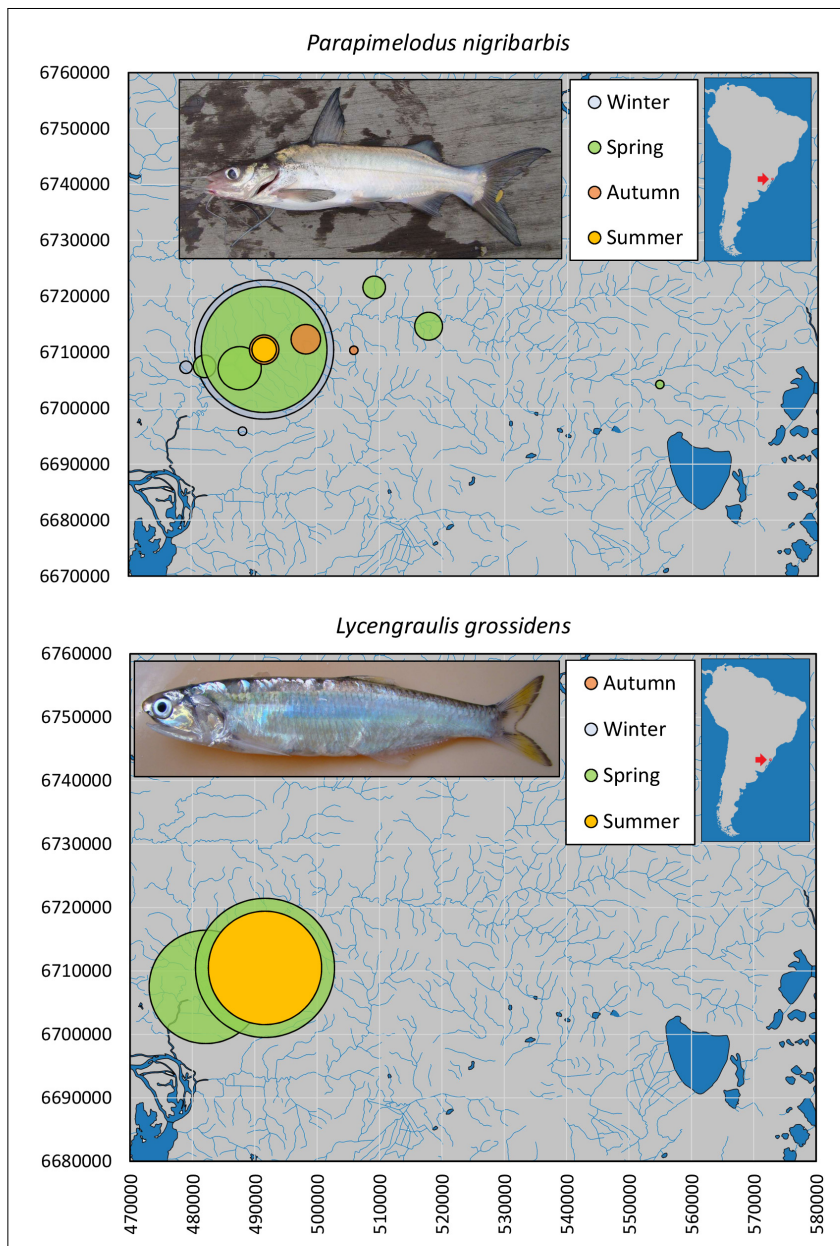

FIGURE 2 | Spatial and seasonal relative abundances of Parapimelodus nigribarbis $(n=459)$ and Lycengraulis grossidens $(n=7)$ in the Sinos River basin, southern Brazil. Bubble area proportional to number of captures per site. Fish photographs from Timm, C.D. available at Fishbase.com. Vector map background from FEPAM open database

(http://www.fepam.rs.gov.br/biblioteca/geo/bases_geo.asp). 22J UTM coordinates.

caught in all seasons in the southernmost portion of Guaíba Lake $(n=63)$, although they were more abundant $(>10 \times)$ during winter months (Figure 6). Museum records of $M$. furnieri in the northern limnetic distribution comprised individuals captured in summer ( $n=3$, MCP 3700, UFRGS 1056 and 8481), autumn ( $n=4$, MCP 25583, 2583, 16334 and 27439) and winter $(n=3$, MCP 28043, 28045 and 28044), with no recorded capture in spring.

The guri sea catfish G. genidens ( $n=27$, Figure 7 ) was captured only in summer, downstream from the middle Guaíba Lake and increasing in relative abundance toward the Patos Lagoon, although there is one museum record upstream in northern Guaíba Lake in November (UFRGS 5819). The size profile comprises adult individuals $(24.5-34.0 \mathrm{~cm}$, median $=27.8 \mathrm{~cm})$.

The few individuals of the white sea catfish G. barbus $(n=7$, Figure 8) were sampled in spring and summer months, only in downstream areas of Guaíba Lake, and comprised mainly large 


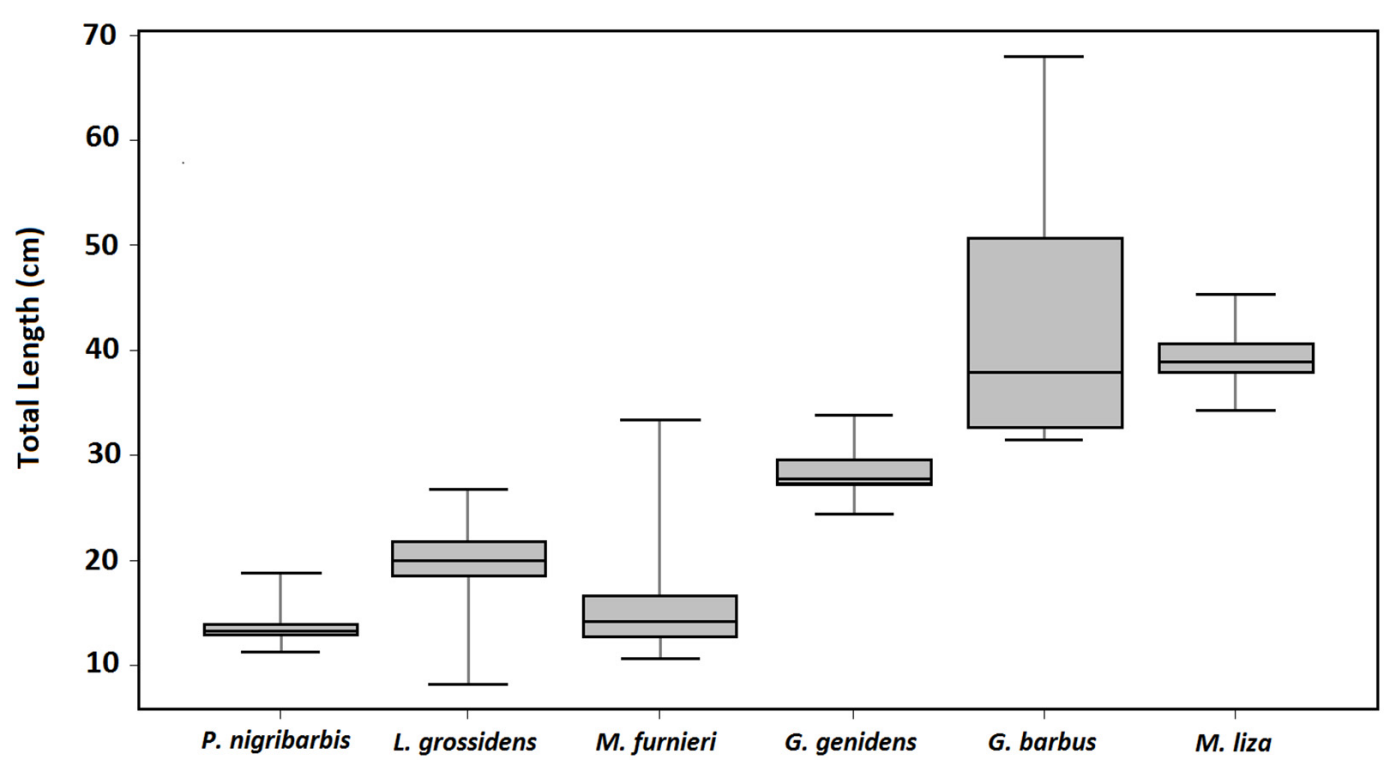

FIGURE 3 | Boxplot of the size profiles (total length, cm) of Parapimelodus nigribarbis, Lycengraulis grossidens, Micropogonias furnieri, Genidens genidens, Genidens barbus and Mugil liza sampled in Guaíba Lake, southern Brazil.

juveniles and adults $(31.5-68.0 \mathrm{~cm}$, median $=37.9 \mathrm{~cm})$. One museum record documents the species in northern Guaíba Lake in October (MCP 3763).

Finally, the gray mullet $M$. liza $(n=13$, Figure 9) appeared in spring and was widespread in the entire Guaíba Lake during the summer, although with no captures in the Sinos River sampling program. The size profile comprised specimens at the borderline of maturity $(34.3-45.5 \mathrm{~cm}$, median $=38.9 \mathrm{~cm})$. Museum data for the species in Guaíba Lake record its presence between November (UFRGS 17771) and March (MCP 14702), with no records in the tributary rivers.

\section{DISCUSSION}

The mandí catfish $P$. nigribarbis feeds on plankton, using filiform and closely spaced gill rakers (Almeida et al., 2013). Marques et al. (2007) found that females measuring $8 \mathrm{~cm}$ (total length) and above had developing ovaries, and estimated the size at first maturity as $13.7 \mathrm{~cm}$. In estuarine areas, $P$. nigribarbis larvae were identified in spring and summer plankton surveys by Muelbert and Weiss (1991).

In monthly samples taken with beach seines in the southern part of Guaíba Lake, Lucena et al. (1994) failed to identify any clear temporal pattern for the species. On the other hand, Bertaco and Becker (2000) observed a seasonal pattern of abundance, although with marked year-to-year variability. According to these authors, the species was present year-round but was more abundant in spring and summer. Bertaco and Becker (2000) proposed a seasonal species movement (potamodromy; Chapman et al., 2012b) from shallow to deeper water in Guaíba Lake, with the fish occupying nearshore areas in spring and summer and deeper water in autumn and winter.
In analyzing reproductive patterns in Guaíba Lake from gillnet captures, Fontoura et al. (2018) found increased GSI values in spring and summer. Nevertheless, the mean GSI values were far below the maximum GSIs recorded, suggesting that the species migrates outside the sampling areas (depth $>1.5 \mathrm{~m}$ ) for spawning.

Based on the available information, the life cycle of $P$. nigribarbis is still obscure. Apparently the species reproduces both in estuarine lentic areas (Muelbert and Weiss, 1991) and far upstream in lotic reaches, as evidenced by the occurrence of larvae in the Jacuí River (November 2017; Santo Amaro Dam; $29.947^{\circ}$ S; $51.893^{\circ} \mathrm{W}$; D.A. Antonetti and D.R. Tataje, personal communication).

The evolution of the coastal plain of Rio Grande do Sul provides an interesting natural experiment concerning the evolution of species occupancy (Figure 10). The coastal plain is about $600 \mathrm{~km}$ long, wide and flat, and has undergone a cycle of oceanic transgressions and regressions during the Pleistocene and Holocene, which gave rise to a complex lagoon system (Rosa et al., 2017). The so-called Barrier I was formed $325 \mathrm{ka}$ ago as a sandy dune system during the first recorded oceanic transgression. Barrier II was formed at $230 \mathrm{ka}$ and Barrier III at $125 \mathrm{ka}$. Barriers I and III now delimit a plain area (with Barrier II between) connecting the northern Patos Lagoon to the Barros Lagoon (Figure 10). This flat area, drained by the Capivarí River (between Barriers I and II) experienced cycles of expansion and retraction of the northern boundary of the Patos Lagoon, reflecting sea-level fluctuations (rises of $9 \mathrm{~m}$ at $230 \mathrm{ka}, 8 \mathrm{~m}$ at $125 \mathrm{ka}$, and $3 \mathrm{~m}$ at $8 \mathrm{ka}$; Rosa et al., 2017).

The southern boundary of Barros Lagoon lies at an altitude of about 18-25 $\mathrm{m}$ a.s.l. (Figure 10), high enough to keep the Barros Lagoon separated from the Patos Lagoon in the last $230 \mathrm{ka}$, although potentially connected by a lagoon spill. Nowadays, 


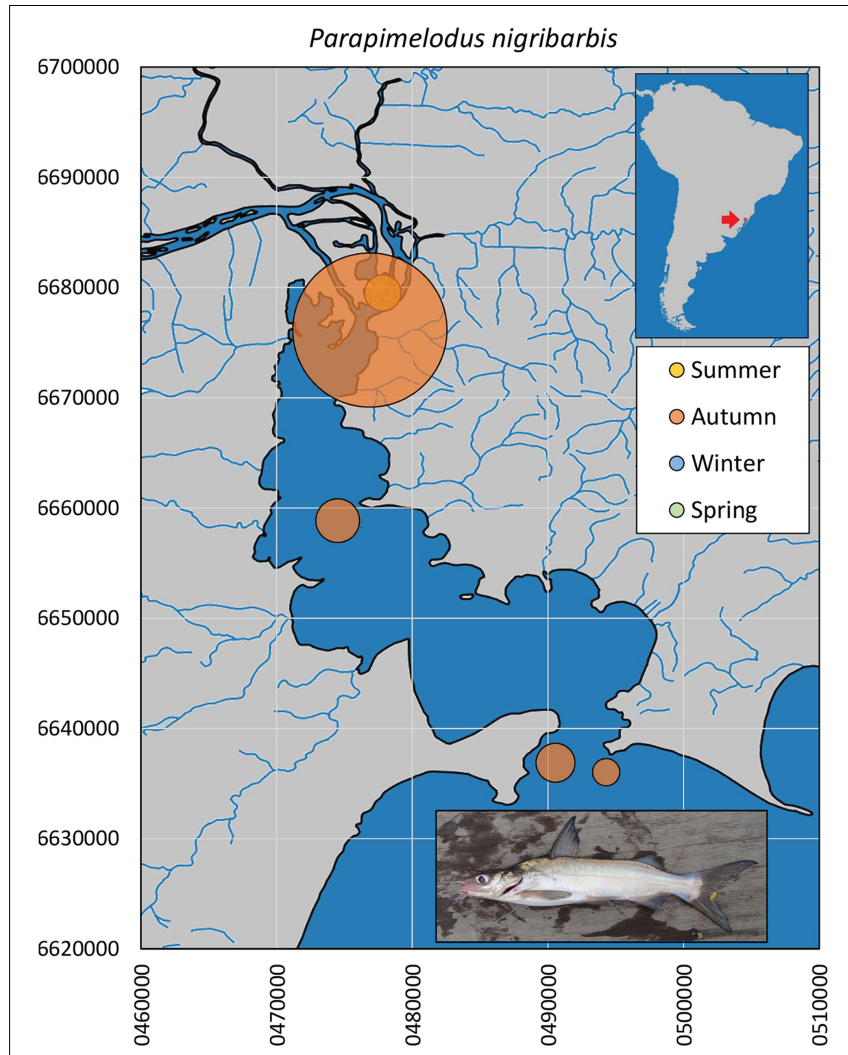

FIGURE 4 | Spatial and seasonal relative abundance of $P$. nigribarbis in Guaíba Lake, southern Brazil. Bubble area proportional to number of captures per site ( $n=149$ individuals). Fish photograph from Timm, C.D. available at Fishbase.com. Vector map background from FEPAM open database (http://www.fepam.rs.gov.br/biblioteca/geo/bases_geo.asp). 22J UTM coordinates.
Barros Lagoon is isolated, receiving only very small tributaries from the Serra Geral coastal mountain range. The ancient connection with the Capivarí River has been completely modified by extensive land use for rice farming, including a network of irrigation channels and water pumping from Barros to rice fields. Nevertheless, before human occupancy, there was probably a connection to the Capivarí basin during winter months, when the lagoon level was higher, and a probable isolation in summer, with increased evaporation and reduced rainfall.

Among the species examined here, only $P$. nigribarbis has been recorded in Barros Lagoon (Museu de Zoologia da Universidade Estadual de Londrina, MZUEL 8426; Museu de Ciências e Tecnologia da PUCRS, MCT 000013907), suggesting that the species is able to reproduce in isolated lakes with no brackish water or any movement to a river channel (landlocked population). In this regard, the high abundance in spring at both ends of its distribution, the Sinos River and the estuary, and spring upstream distribution records in the Taquarí and Sinos rivers, all suggest no clear pattern of upstreamdownstream movements. On the other hand, Oldani et al. (2007) recorded Parapimelodus valenciennis as a dominant species passing through the Borland fishpass at Salto Grande Dam on

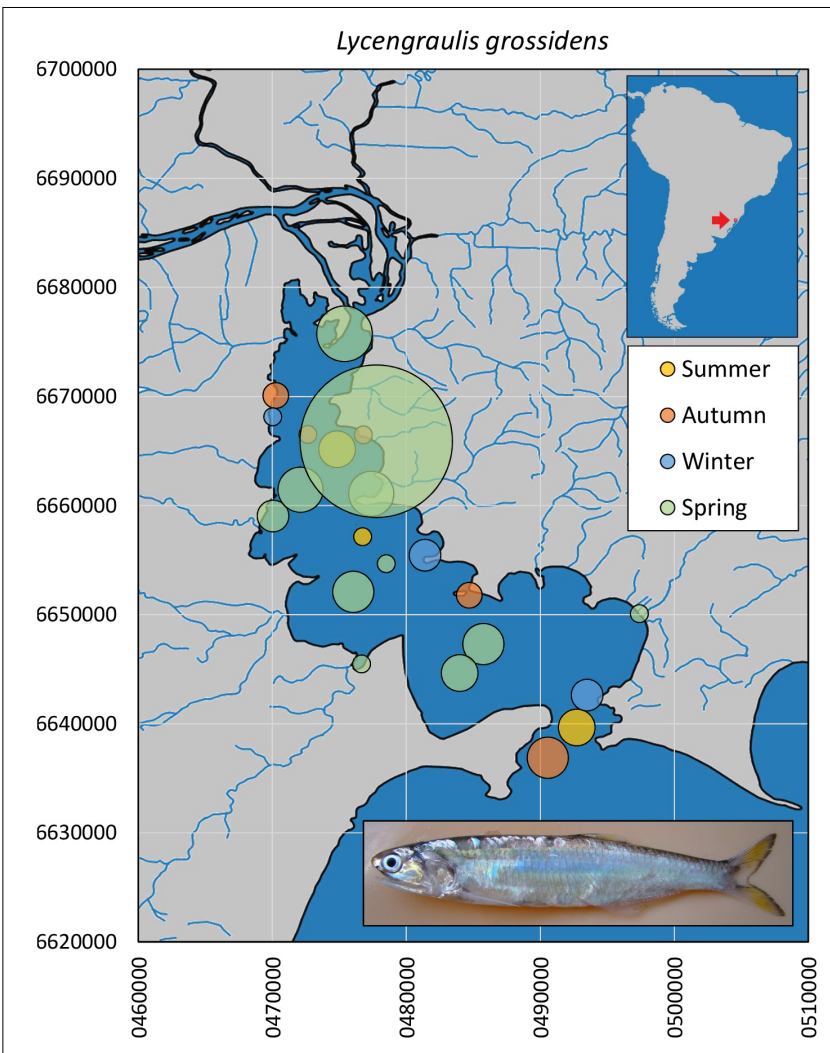

FIGURE 5 | Spatial and seasonal relative abundance of $L$. grossidens in Guaíba Lake, southern Brazil. Bubble area proportional to number of captures per site ( $n=134$ individuals). Fish photograph from Timm, C.D. available at Fishbase.com. Vector map background from FEPAM open database (http://www.fepam.rs.gov.br/biblioteca/geo/bases_geo.asp). 22J UTM coordinates.

the Uruguay River, which suggests some degree of upstreamdownstream movement for this congener of $P$. nigribarbis.

At this time, the original suggestion by Bertaco and Becker (2000), of movements from shallow to deeper water, is certainly possible. The information gaps indicate the need for additional sampling programs to reach a full understanding of $P$. nigribarbis biology, including larval surveys and a program of seasonal sampling with both seines and gillnets along the full gradient of the Patos Lagoon, from a large tributary (including marginal lagoons) to the estuarine region. In addition, otolith lifetime transects of Sr:Ca and Ba:Ca could be very informative to identify any movement from fresh to more-saline waters (Chapman et al., 2012b). Although P. nigribarbis could be found from estuarine waters to far upstream in seasonal patterns of abundance, with the sampling gear used, the species cannot be classified as diadromous and is apparently an opportunistic potamodromous planktivorous fish that reproduces throughout its distributional range.

A recent review of the Atlantic sabretooth anchovy L. grossidens biology was presented by Mai and Vieira (2013). Reproduction of the species is reported for spring and summer months, and the size at first maturity is estimated 


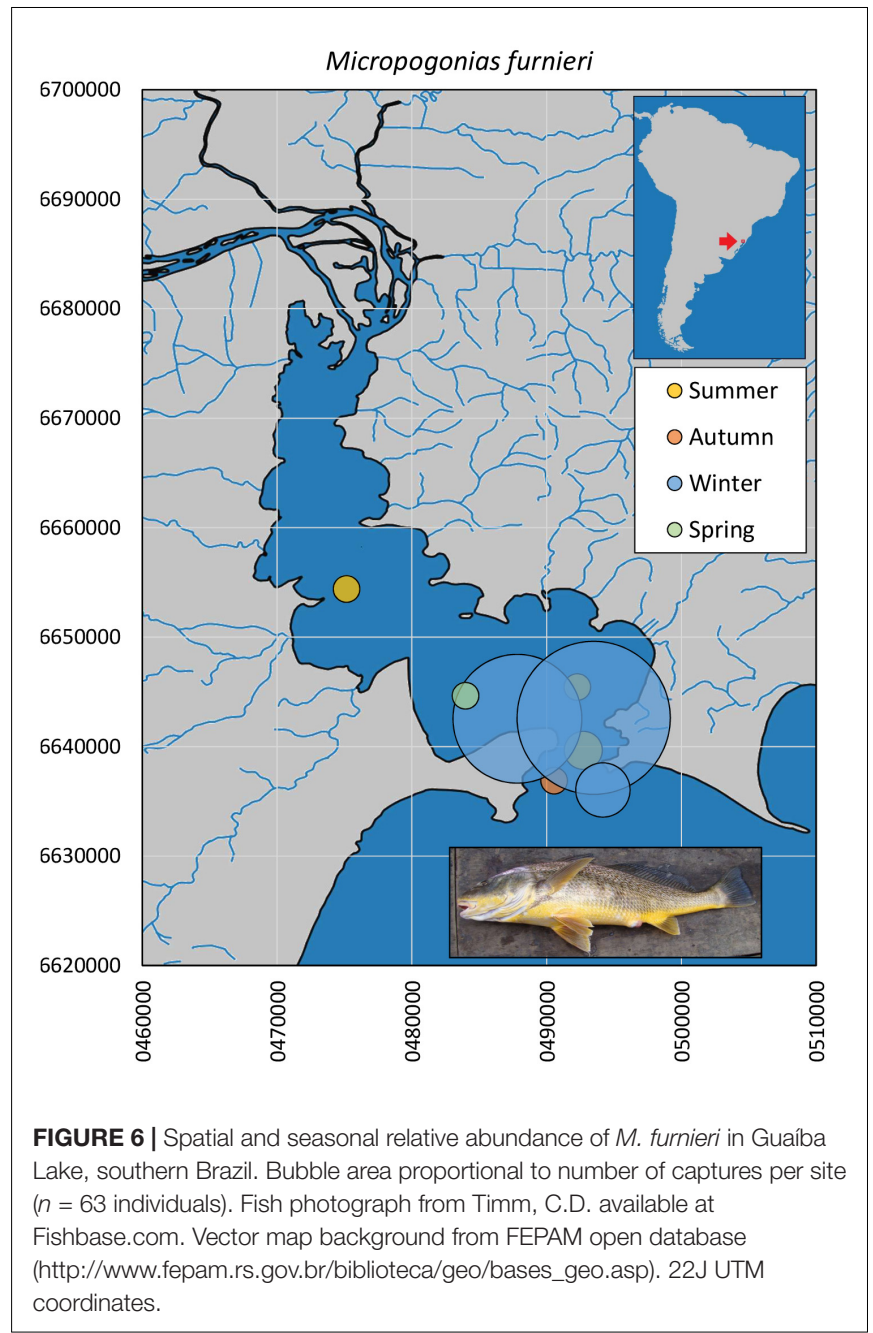

in the $8.0-13.3 \mathrm{~cm}$ range (total length) (Mai and Vieira, 2013). The species shows a marked shift in feeding habits, changing at $\sim 10 \mathrm{~cm}$ from planktivorous to ichthyophagous (Fontoura et al., 2015).

Lycengraulis grossidens is eurytopic in fresh to coastal waters (Whitehead et al., 1988; Barletta et al., 2010) and was classified as facultatively amphidromous by Mai et al. (2014). Although described as an estuarine reproducer, the species is presumed to spawn in fresh water because larvae (reported as Lycengraulis olidus) have been found immediately downstream from the Salto Grande Dam on the Uruguay River, roughly $370 \mathrm{~km}$ upstream from the Uruguay-Paraná Delta (Fuentes et al., 2016).

By analyzing the Sr:Ca and Ba:Ca ratios, Mai et al. (2014) identified at least four distinct patterns of habitat use for L. grossidens: freshwater residents, estuarine/marine residents, and two distinct diadromous/nomadic types. Nevertheless, even the so-called freshwater stocks are not completely isolated. Oldani et al. (2007) reported L. grossidens as a dominant species in the Borland fishpass system at the Salto Grande Dam on the Uruguay River, although they provided no information on the direction of the movements. Unfortunately, live-time $\mathrm{Sr}: \mathrm{Ca}$

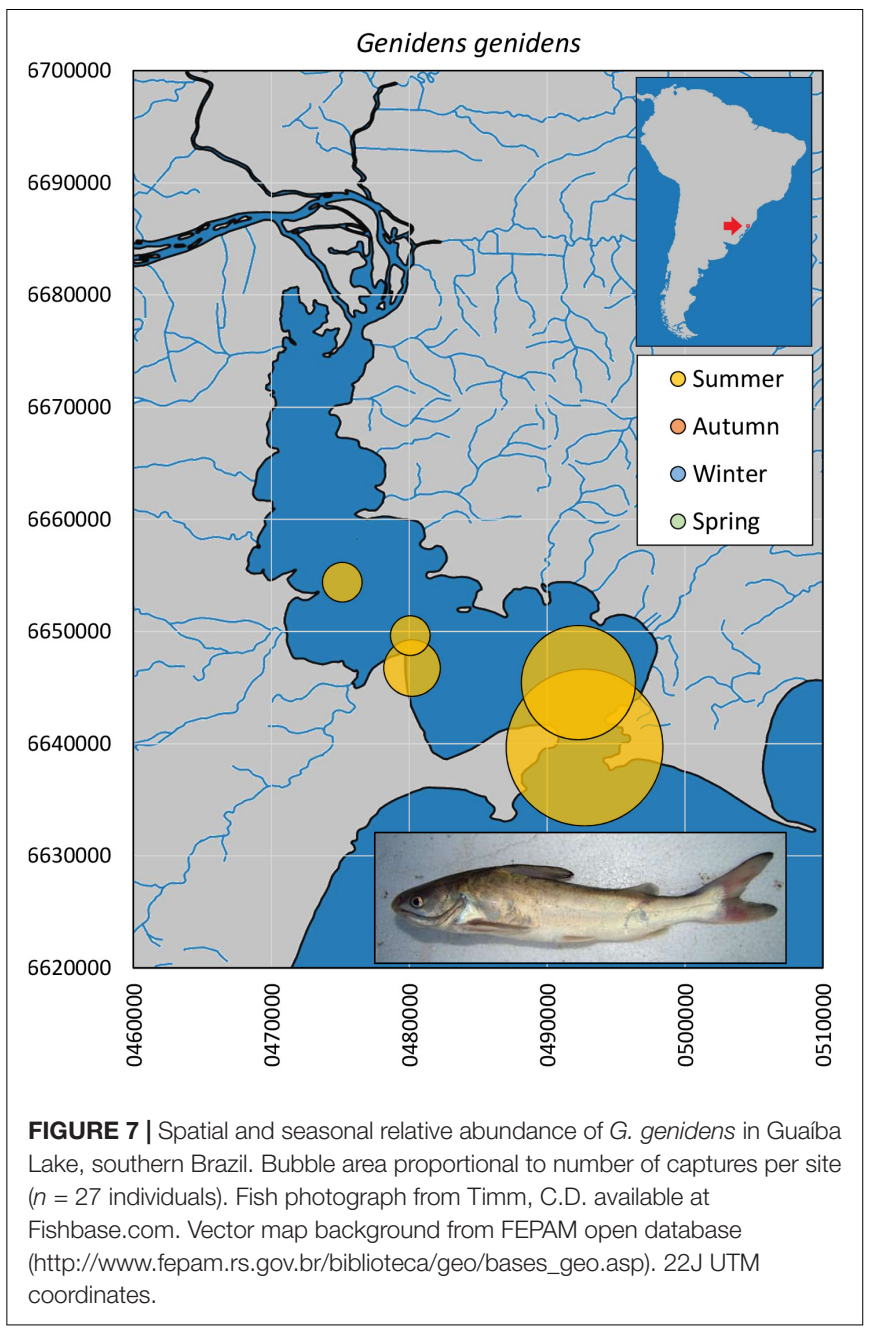

and $\mathrm{Ba}: \mathrm{Ca}$ ratios for L. grossidens in the Uruguay River were reported for only one specimen by Mai et al. (2014). They found a marked change in the $\mathrm{Sr}: \mathrm{Ca}$ and $\mathrm{Ba}: \mathrm{Ca}$ ratios measured before and after the first annulus. Younger fish showed higher ratios of Ba:Ca and Sr:Ca, typical of freshwater development; but after the first annulus, the $\mathrm{Ba}: \mathrm{Ca}$ and $\mathrm{Sr}: \mathrm{Ca}$ values became more similar, suggesting a possible movement between habitats or an ontogenetic shift in ion absorption-deposition.

Mitochondrial DNA analysis (control region, 1017 bp) of fish from estuarine areas in southern Brazil (Patos Lagoon and Mampituba River), the La Plata estuary and a landlocked population in the Uruguay River (Mai et al., 2016) revealed increased haplotype diversity in estuarine samples. Although most fish from the Uruguay River grouped together with all estuarine L. grossidens, Mai et al. (2016) found a clade of low diversity and exclusive haplotypes in the Uruguay River samples, a clade segregated from estuarine samples (except for one individual) and closer to the outgroup (Lycengraulis poeyi). According to Mai et al. (2016), the haplotype structure suggests that the Uruguay population is an ancestral lineage and the phylogenetic history is compatible with a north-to-south 


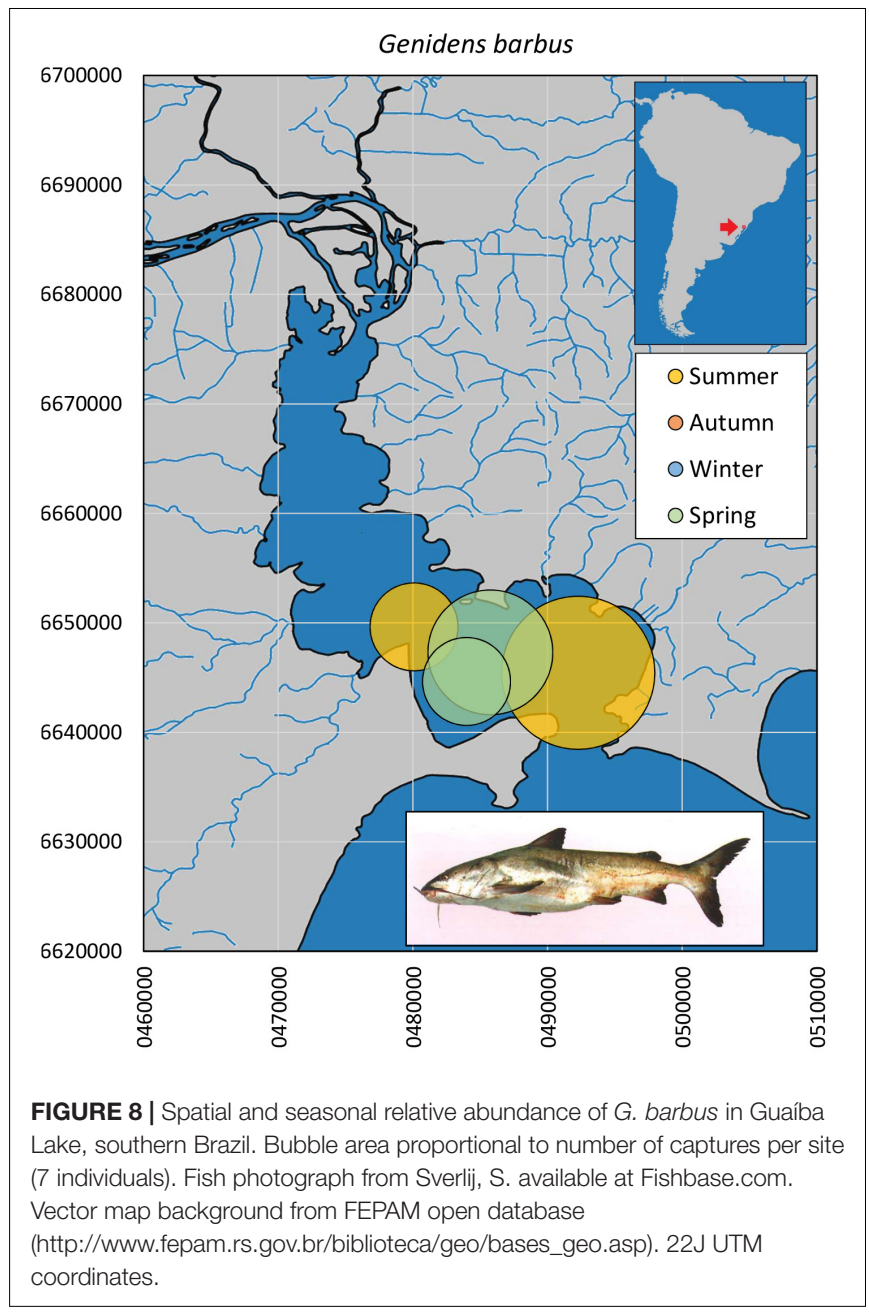

continental colonization route from the Amazon to the ParanáUruguay basins. In this respect, the transition to estuary and coastal regions would be a new evolutionary event.

Nevertheless, a broader interpretation of the distribution pattern of the species could go in another direction. Considering the coastal lagoons of Rio Grande do Sul, L. grossidens is not present in Barros Lagoon, although presumed to be present (as P. nigribarbis) in regard to the ancient Barros-Patos connection. The species is also absent from other isolated coastal lagoons (L.H. R. Rodrigues, personal communication) that were formed in the last oceanic regression around 5-8 ka ago, although present in lagoons with some connection to the sea. Therefore, the question arises of why the species disappeared from closed coastal lagoons where it was presumed to be present some time ago (hundreds or thousands of years), but is still present as a landlocked population in the Uruguay River?

One hypothesis is that the species is able to reproduce successfully in fresh water, a hypothesis supported by the presence of larvae immediately downstream from Salto Grande Dam (we assume that larvae will not migrate $>300 \mathrm{~km}$ upstream from estuarine areas, swimming against strong river currents). This hypothesis was suggested long ago, during a sampling

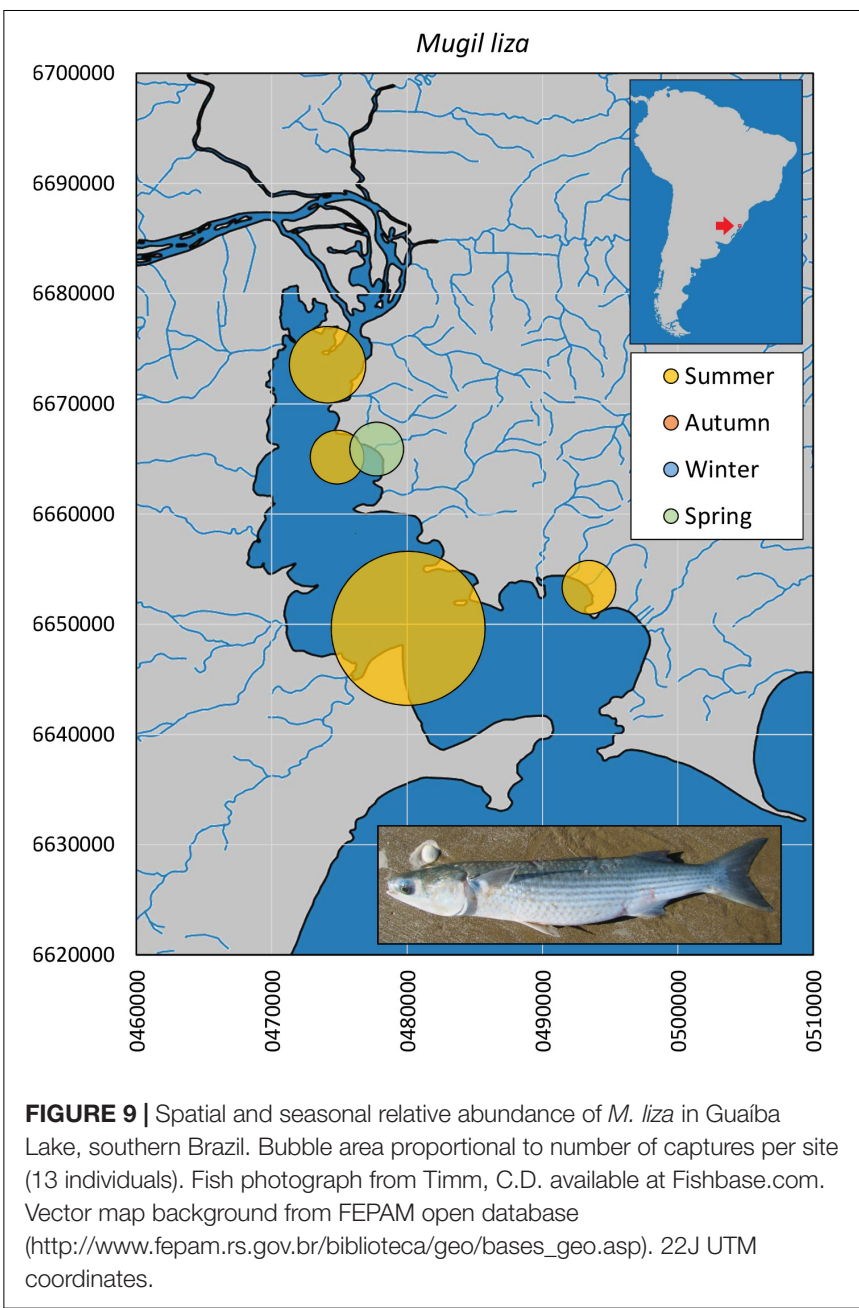

program in the Fortaleza Lagoon $\left(30.130^{\circ} \mathrm{S}, 50.234^{\circ} \mathrm{W}\right)$ in 1992 , when specimens of L. grossidens only $4.0 \mathrm{~cm}$ long were found upstream from a small dam $(\sim 1 \mathrm{~m}$ high) that obstructed the route from estuarine areas only $10 \mathrm{~km}$ downstream. Although a 1-m leap is easy for many fish species, this is probably not the case for L. grossidens individuals only $4 \mathrm{~cm}$ long, as they are proportionally very long and fragile.

A possible hypothesis is that in freshwater conditions, eggs and larvae are under increased stress, with consequently reduced viability. This hypothesis could explain why the species is now absent from isolated coastal lagoons, although it had the opportunity to colonize them within the last few thousand years. This hypothesis also explains the lower haplotype diversity in the Uruguay River in comparison with estuarine samples, a result of possible selective pressures. In this regard, the exclusive haplotypes in the Uruguay River could be the result of strong selection pressures, making some haplotypes frequent that in estuarine areas are rare and therefore are not collected. This hypothesis also agrees with the higher haplotype diversity in estuarine areas.

However, why did Mai et al. (2016) conclude exactly the opposite, inferring that the Uruguay River stock is an ancestral 


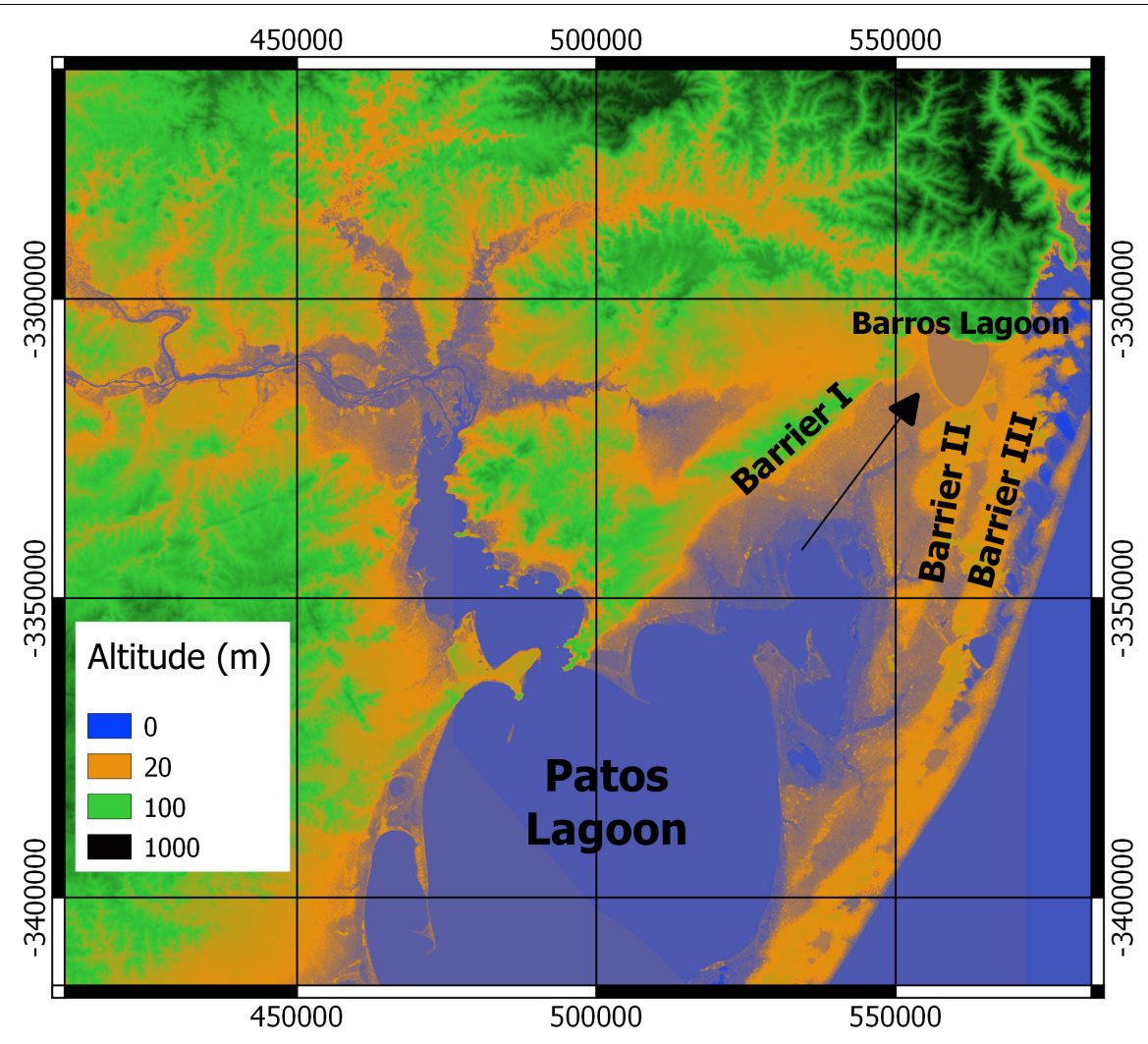

FIGURE 10 | Northern Patos Lagoon and depositional sand barriers from marine transgressions and regressions during the Pleistocene. Barriers I, II and III were formed at 325, 230 and 125 thousand years, respectively (Rosa et al., 2017). Arrow indicates a possible connection between Patos Lagoon and Barros Lagoon through lowland areas. Digital Elevation Model at 30 × 30 m resolution (EPSG:32622 - WGS 84/UTM zone 22N - Projected).

lineage after applying several tools for genetic analysis? This could be because these authors interpreted their data as populations in Hardy-Weinberg equilibrium, which is probably not true for the Uruguay stock. If we are correct, the Uruguay population above Salto Dam could be suffering from selective pressures, especially on the egg and larval stages, and could become extinct in the near future, as in the isolated coastal lagoons of Rio Grande do Sul. The extinction process could last from hundreds to thousands of years, but is a plausible scenario.

Concerning the data analyzed in the present study, L. grossidens was restricted to lower stretches of the Sinos River in spring and summer months, while present year-round throughout the lake in Guaíba Lake, although tenfold more abundant in spring, indicating seasonal movement. Although we used gillnets exclusively, Lucena et al. (1994) used beach seine nets (5-mm mesh) in monthly samples, with larger catches in autumn and spring, and caught several individuals as small as $4 \mathrm{~cm}$ in April 1990. These tiny specimens either hatched in fresh water or migrated $>200 \mathrm{~km}$ from estuarine waters.

Nevertheless, as for $P$. nigribarbis, these information gaps require further investigation, and programs to sample plankton from the upper Patos basin to the estuarine region should be developed in the future. Although this complex species continues to defy our understanding, it seems that L. grossidens is a partial migrator sensu Chapman et al. (2012a), and also has a very versatile lifestyle (life-history polymorphism), with part of the population migrating from fresh water to estuaries for spawning (semi-catadromy), some remaining in fresh water (with no identified movement pattern), and some moving from marine environments to brackish waters for spawning (semi-anadromy) (Chapman et al., 2012b; Mai and Vieira, 2013, Mai et al., 2014). However, as the movements involve reproduction, it seems more appropriate to classify the species as facultatively diadromous instead of facultatively amphidromous sensu Mai et al. (2014).

The whitemouth croaker $M$. furnieri is classified as an estuarine-dependent species and can be found from the upper limnetic part of the Patos Lagoon to the adjacent marine surf zone and shelf, using estuaries as nursery grounds (Costa et al., 2014). Size at sexual maturity is in the range of $18-20 \mathrm{~cm}$ (Castello, 1986), with a spring-summer migration to reproduce in saline waters (Muelbert and Weiss, 1991).

Costa et al. (2015) modeled the spatial and temporal distribution patterns of the species in the estuarine area of the Patos Lagoon. Maps of the presumed distribution were presented for different size classes and season of the year. Although the authors studied a limited area, comprising roughly the southernmost $10 \%$ of the lagoon (estuary), there was a clear spatial distribution pattern, with small individuals in both the 30-90 $\mathrm{mm}$ and 90-160 $\mathrm{mm}$ ranges expanding their distribution northward to less-saline waters in winter and spring. 
Records from museum specimens for $M$. furnieri in the core of the Patos Lagoon are sparse (MCP 9121-9124, 9141), except for the north (Guaiba) and south (estuary) ends. Dated samples $(n=10)$ from the northern limnetic distribution comprised individuals captured in summer $(n=3$, MCP 3700, UFRGS 1056 and 8481), autumn ( $n=4$, MCP 25583, 2583, 16334 and 27439) and winter ( $n=3$, MCP 28043, 28045 and 28044), with no catches recorded in spring. Lucena et al. (1994), from monthly samples taken with a beach seine in southern Guaíba Lake, recorded only two captures of $M$. furnieri in autumn. In a more-recent sampling program, using surface and bottom gillnets (adjacent knots: 35, 40, 45, 50, 55, 60 and $65 \mathrm{~mm}$ ), Ceni et al. (2016) captured M. furnieri in the northern Patos Lagoon in the size range of 10$55 \mathrm{~cm}$ (total length). The species was present year-round and was 3-4-fold more abundant from August to October. Summarizing the available information, $M$. furnieri is well distributed along the Patos Lagoon and Guaíba Lake, although with no recorded occurrence in tributary rivers forming the Guaíba Delta. Even though it is present year-round in both limnetic (lagoon and lake) and estuarine areas, there is a pattern of spring and summer migration to reproduce in more-saline waters.

The available data add new evidence to clarify the general pattern for the spatial and temporal distribution of M. furnieri. First, the species does not move toward the rivers forming the Patos Basin, as no specimens were caught in the extensive Sinos River sampling program, in agreement with its absence from museum collections. Unfortunately, the smallest mesh size used by Ceni et al. (2016) was $35 \mathrm{~mm}$ (adjacent knots), and direct comparison of the species size profile with the present samples (taken using mesh sizes from $15 \mathrm{~mm}$ ) is not possible. Nevertheless, it is clear that $M$. furnieri could be present in the northern Patos Lagoon and Guaíba Lake during all months of the year, from juveniles to adults, although mostly juveniles occur in southern Guaíba Lake in winter. The anadromous migration pattern could be more complex, with possible partial migration. Movement from coastal waters to the estuary for spawning is well established (Muelbert and Weiss, 1991), but the seasonal estuarine pattern proposed by Costa et al. (2015) is more complex than described, as the species could spread far beyond into fresh waters. A general pattern of higher winter abundance in northern fresh waters prior to a spring spawning in the estuary suggests a more-complex migration pattern. Also, the presence of adult M. furnieri in the northern Patos Lagoon year-round (Ceni et al., 2016) suggests a more intricate pattern of habitat occupation (life-style polymorphism), with adult individuals not returning to the sea after reproducing, and perhaps spending their entire lives in fresh to brackish waters. Analysis of the $\mathrm{Sr}: \mathrm{Ca}$ and $\mathrm{Ba}: \mathrm{Ca}$ ratios is needed to resolve these questions, and a full understanding of M. furnieri life history is still to come.

Three species of marine catfishes have historically been recorded in Patos Lagoon: G. barbus, G. genidens and Genidens planifrons (Chao et al., 1985; Reis, 1986), although only G. barbus and G. genidens were captured in Guaíba Lake in the present study. According to Brazilian regulations (Portaria MMA 445/2014) G. barbus is considered Endangered (EN) and G. planifrons Critically Endangered (CR), with captures and trade forbidden (RS State Law No. 5 797, 2014).
Ceni et al. (2016), describing the artisanal fishery in the northern Patos Lagoon, reported that G. barbus had a 25-fold larger captured biomass than G. genidens. In the present study, both species were captured in small numbers in the southern Guaíba Lake, although G. genidens was far more abundant (G. genidens, $n=27$; G. barbus, $n=7$ ). The biomasses for the two species were quite similar $(\sim 6 \mathrm{~kg})$, suggesting that the artisanal fishery targets G. barbus in the northern Patos Lagoon by selecting larger gillnet mesh sizes.

Genidens barbus is a typical anadromous species, migrating from coastal to estuarine waters for spawning, where the males mouth-breed eggs and juveniles (Reis, 1986; Haimovici, 1997). Nevertheless, the seasonal patterns of occurrence of Genidens catfishes in the northern Patos Lagoon and Guaíba Lake are still obscure, with contradictory information. Milani and Fontoura (2007), monitoring fishery landings of marine catfish (Genidens, but with no species identification) identified captures during all months of the year, but with no clear pattern in the 2002 survey, although they reported higher landings from May through September in 2004. This contradictory result was explained by a moderate El Nino in 2003-2004, which caused higher rainfall in southern Brazil and may have affected the Genidens reproductive and migratory cycles.

Ceni et al. (2016), monitoring an artisanal fishery in the northern Patos Lagoon, also observed that both G. barbus and G. genidens were present during all months of the year, with higher abundances from August through January. This cycle agrees with the descriptions by Reis (1986) and Haimovici (1997), but conflicts with the higher abundances in May through September reported by Milani and Fontoura (2007) in 2004 landings.

In the present study, G. genidens was captured only in summer (mainly January and some in February) in the southern Guaíba Lake, whereas G. barbus was captured in spring and summer (beginning of December through January). Both species were captured in the downstream areas of Guaíba Lake, and none in the Sinos River. By checking museum records, more upstream movements for both species were identified, with recorded occurrences in the northern Guaíba Lake in October and November (G. barbus, MCP 3763; G. genidens, UFRGS 5819).

The low captures of both species are not sufficient to establish a clear cycle of occurrence, but one must note that some specimens were caught in the far-upstream part of the range just when the described reproductive cycle would predict movement to coastal waters (Reis, 1986; Haimovici, 1997). The available data and the landings reported by Milani and Fontoura (2007) suggest that the migratory cycles of Genidens species could be much more complex than previously described, with remarkable plasticity in the way that individuals respond to environmental factors. Although both species could be classified as anadromous, they show complex movement patterns that may include partial migration.

The life cycle of the gray mullet $M$. liza comprises reproductive migrations each autumn from Argentina and southern Brazil to spawn between northern Santa Catarina and Paraná (Lemos et al., 2014), with juveniles migrating to estuarine areas to grow, in a 
typical catadromous strategy (Vieira, 1991; Vieira and Scalabrin, 1991; Lemos et al., 2014).

The present data show that M. liza was present throughout Guaíba Lake during spring and summer, although not caught in the Sinos River. Occurrence data from museum specimens record its presence from November (UFRGS 17771) to March (MCP 14702) in Lake Guaíba, with no records in tributary rivers. Interestingly, the species was present in the Dilúvio River, a small and very eutrophic channeled river receiving Porto Alegre city drainage and untreated domestic sewage. The reason that $M$. liza (with the introduced cf. Oreochromis niloticus) is attracted to these heavily polluted waters is unknown, but probably related to organic-rich sediments (cf. YouTube videos of M. liza caught in the Dilúvio River $)^{2,3}$.

Milani and Fontoura (2007) reported captures of M. liza in the northern Patos Lagoon during all months of the year, but with a marked increase from October through February, mainly during the fishery closed season (November 1 to January 31 in the northern Patos Lagoon). On the other hand, in a more recent survey, Ceni et al. (2016) did not record captures during the closed season. The mullet was captured by the artisanal fleet from February to October and was 5-6 times more abundant from August through October (280 individuals $10,000 \mathrm{~m}^{-2}$ day $^{-1}$ ). If one compares scientific captures with a set of mesh sizes, including smaller mesh sizes than are usually used by the artisanal fishery, M. liza showed increased captures from February to April, probably mainly sub-adults. In this regard, this mullet is present year-round in fresh waters, mainly lentic ones, with lower abundances of adults during the autumn and winter when most adults are moving to coastal waters for spawning. Although this general cycle has been described previously, the upstream limits of the mullet in the Patos Lagoon are now better documented.

\footnotetext{
${ }^{2}$ https://www.youtube.com/watch?v=W25yUE7BdZc

${ }^{3}$ https://www.youtube.com/watch?v=txMejbrZDtQ
}

\section{REFERENCES}

Acero, A., and Bentancur, R. (2010). Genidens Genidens (Errata Version Published in 2017). The IUCN Red List of Threatened Species 2010: e.T154640A115216247. doi: 10.2305/IUCN.UK.2010-4.RLTS.T154640A4595067.en

Almeida, A. P. G., Behr, E. R., and Baldisserotto, B. (2013). Gill rakers in six teleost species: influence of feeding habit and body size. Ciênc. Rural 43, 2208-2214. doi: 10.1590/S0103-84782013005000142

Barletta, M., Jaureguizar, A. J., Baigun, C., Fontoura, N. F., Agostinho, A. A., Almeida-Val, V. M. F., et al. (2010). Fish and aquatic habitat conservation in South America: a continental overview with emphasis on neotropical systems. J. Fish Biol. 76, 2118-2176. doi: 10.1111/j.1095-8649.2010.02684.x

Bertaco, V. A., and Becker, F. G. (2000). Observações sobre as capturas de Parapimelodus nigribarbis (Pimelodidae) no Lago Guaíba. Comunicações do Museu de Ciências e Tecnologia da PUCRS, Série Zoologia 13, 185-195.

Castello, J. P. (1986). Distribucion, crecimiento y maduracion sexual de la corvina juvenil (Micropogonias furnieri) en el estuário de la Lagoa dos Patos. Brasil. Physis 44, 21-36.

Ceni, G., Fontoura, N. F., and Cabral, H. N. (2016). The freshwater artisanal fishery of Patos Lagoon. J. Fish. Biol. 89, 337-354. doi: 10.1111/jfb.13004

Chao, L. H., Pereira, L. E., and Vieira, J. P. (1985). "Estuarine fish community of the dos Patos Lagoon, Brazil: a baseline study," in Fish Community Ecology in Estuaries and Coastal Lagoons: Towards an Ecosystem Integration, ed. A. Yáñez-Arancibia (Ciudad de México: UNAM Press), 429-450.
Finally, the new data presented here and comparison with information available in the literature improved the understanding of the movements of fish between fresh, estuarine and ocean waters. Nevertheless, some information gaps are still in need of further investigation, especially the midsection of the large Patos Lagoon and its main tributary, the Jacuí River. For both, systematic sampling programs directed toward all life stages, larvae, juveniles and adults, are mandatory to fill the existing lacunae in knowledge, for a better understanding of fish biology and to support environmental management policies.

\section{ETHICS STATEMENT}

This research was approved by the Comissão de Ética no Uso de Animais (Ceua - PUCRS) and all animal collections were approved by IBAMA.

\section{AUTHOR CONTRIBUTIONS}

NF organized the Guaíba sampling project and prepared the first version of the manuscript. US performed the Sinos River sampling project and revised the manuscript. TA and TS conducted the Guaíba sampling program, sampling trial, and organization, and revised the manuscript. JP organized the Sinos data set and revised the manuscript. DA participated in the Sinos River sampling program and revised the manuscript.

\section{ACKNOWLEDGMENTS}

Research supported by Conselho Nacional de Desenvolvimento Científico e Tecnológico - CNPq: 307485/2014-5; 303973/2017-0; 307455/2016-5; 140440/2011-9; 140389/2011-3.

Chapman, B. B., Hulthén, K., Brodersen, J., Nilsson, P. A., Skov, C., Hansson, L.-A., et al. (2012a). Partial migration in fishes: causes and consequences. J. Fish. Biol. 81, 456-478. doi: 10.1111/j.1095-8649.2012.03342.x

Chapman, B. B., Skov, C., Hulthén, K., Brodersen, J., Nilsson, P. A., Hansson, L.A., et al. (2012b). Partial migration in fishes: definitions, methodologies and taxonomic distribution. J. Fish. Biol. 81, 479-499. doi: 10.1111/j.1095-8649. 2012.03349.x

Costa, M. D. P., Muelbert, J. H., Moraes, L. E., Vieira, J. P., and Castello, J. P. (2014). Estuarine early life stage habitat occupancy patterns of whitemouth croaker Micropogonias furnieri (Desmarest, 1830) from the Patos Lagoon. Brazil. Fish. 160, 77-84. doi: 10.1016/j.fishres.2013.10.025

Costa, M. D. P., Muelbert, J. H., Vieira, J. P., and Castello, J. P. (2015). Dealing with temporal variation and different life stages of whitemouth croaker Micropogonias furnieri (Actinopterygii, Sciaenidae) in species distribution modeling to improve essential estuarine fish habitat identification. Hydrobiologia 762, 195-208. doi: 10.1007/s10750-0152348-4

Fontoura, N. F., Ceni, G., Braun, A. S., and Marques, C. S. (2018). Defining the reproductive period of freshwater fish species of the patos lagoon basin using the gonadosomatic index: a proposed protocol applied to ten species of the Patos Lagoon basin. Neotrop. Ichthyol. 16:e170006. doi: 10.1590/1982-022420170006

Fontoura, N. F., Rodrigues, L. R., Batista, C. B., Persch, T. S. P., and Janowicz, M. E. (2015). Integrating ontogenetic shift, growth and mortality to determine 
a species' ecological role from isotopic signatures. PLoS One 10:e0125059. doi: 10.1371/journal.pone.0125059

Fontoura, N. F., Vieira, J. P., Becker, F. G., Rodrigues, L. R., Malabarba, L. R., Schulz, U. H., et al. (2016). Aspects of fish conservation in the upper Patos Lagoon basin. J. Fish. Biol. 89, 315-336. doi: 10.1111/jfb.13005

Fuentes, C. M., Gómez, M. I., Brown, D. R., Arcelus, A., and Ros, A. E. (2016). Downstream passage of fish larvae at the salto grande dam on the uruguay river. River Res. Appl. 32, 1879-1889. doi: 10.1002/rra.3030

Garcia, A. M., Raseira, M. B., Vieira, J. P., Winemiller, K. O., and Grimm, A. M. (2003). Spatiotemporal variation in shallow-water freshwater fish distribution and abundance in a large subtropical coastal lagoon. Environ. Biol. Fish. 68, 215-228. doi: 10.1023/A:1027366101945

Haimovici, M. (1997). Recursos Pesqueiros Demersais da Região Sul. Brasília: Ministério do Meio Ambiente, dos Recursos Hídricos e da Amazônia Legal (MMA), Comissão Interministerial para os Recursos do Mar (CIRM) e Fundação dos Estudos do Mar (FEMAR).

Isaac, V. J. (1988). Synopsis of biological data on the whitemouth croaker Micropogonias furnieri (Desmarest, 1823). FAO Fish. Synopsis 150, 1-35.

Lemos, V. M., Varela, A. S. Jr., Schwingel, P. R., Muelbert, J. H., and Vieira, J. P. (2014). Migration and reproductive biology of Mugil liza (Teleostei: Mugilidae) in south Brazil. J. Fish Biol. 85, 671-687. doi: 10.1111/jfb. 12452

Lucena, C. A. S., Carlos, A. S. L., Aldo, S. J., and Vidal, E. S. (1994). Ocorrência, distribuição e abundância da fauna de peixes da praia de Itapuã, Viamão, Rio Grande do Sul. Comunicações do Museu de Ciências da PUCRS, Série Zoologia 7, 3-27.

Lucena, C. A. S., Malabarba, L., and Reis, R. (1992). Resurrection of the Neotropical Pimelodid Catfish Parapimelodus nigribarbis (Boulenger), with a Phylogenetic Diagnosis of the Genus Parapimelodus (Teleostei: Siluriformes). Copeia 1992, 138-146. doi: 10.2307/1446545

Mai, A. C. G., Condini, M. V., Albuquerque, C. Q., and Vieira, J. (2014). High plasticity in habitat use of Lycengraulis grossidens (Clupeiformes. Engraulididae). Estuar. Coast. Shelf. Sci. 141, 17-25. doi: 10.1016/j.ecss.2014. 01.014

Mai, A. C. G., Robe, L. J., Marins, L. F., and Vieira, J. P. (2016). Genetic relationships between landlocked and coastal populations of Lycengraulis grossidens (Engraulidae) in south-eastern South America: evidence for a continental colonisation route with secondary transitions to the coastal region. Mar. Freshw. Res. 68, 342-351. doi: 10.1071/MF15355

Mai, A. C. G., and Vieira, J. P. (2013). Review and consideration on habitat use, distribution and life history of Lycengraulis grossidens (Agassiz, 1829) (Actinopterygii, Clupeiformes, Engraulididae). Biota Neotrop. 13, 121-130. doi: 10.1590/S1676-06032013000300015

Marques, C. S., Braun, A. S., and Fontoura, N. F. (2007). Estimativa de tamanho de primeira maturação a partir de dados de IGS: Oligosarcus jenynsii, Oligosarcus robustus, Hoplias malabaricus, Cyphocharax voga, Astyanax fasciatus (Characiformes), Parapimelodus nigribarbis, Pimelodus maculatus, Trachelyopterus lucenai, Hoplosternum littorale, Loricariichthys anus (Siluriformes) e Pachyurus bonariensis (Perciformes) no Lago Guaíba e Laguna dos Patos, RS. Biociências 15, 230-256.
Menezes, N. A., Oliveira, C., and Nirchio, M. (2010). An old taxonomic dilemma: the identity of the western south Atlantic lebranche mullet (Teleostei: Perciformes: Mugilidae). Zootaxa 2519, 59-68. doi: 10.11646/zootaxa. 2519.1.4

Metcalfe, J., and Craig, J. F. (2012). Fish migration in the 21st Century: opportunities and challenges. J. Fish. Biol. 81, 361-364. doi: 10.1111/j.10958649.2012.03388.x

Milani, P. C. C., and Fontoura, N. F. (2007). Diagnóstico da pesca artesanal na lagoa do Casamento, sistema nordeste da laguna dos Patos: uma proposta de manejo. Biociências 15, 82-125.

Muelbert, J., and Weiss, G. (1991). Abundance and distribution of fish larvae in the channel area of the Patos Lagoon estuary, Brazil. NOAA Tech. Rep. Ser. 95, 43-54.

Oldani, N. O., Baigún, C. R. M., Nestler, J. M., and Goodwin, R. A. (2007). Is fish passage technology saving fish resources in the lower La Plata River basin? Neotrop. Ichthyol. 5, 89-102. doi: 10.1590/S1679-62252007000 200002

Reis, E. G. (1986). A pesca artesanal de bagres marinhos (Siluriformes, Ariidae) no estuário da Lagoa dos Patos (RS), Brasil. Rio Grande 05, 7-21.

Rosa, M. L. C. C., Barboza, E. G., Abreu, V. S., Tomazelli, L. J., and Dillenburg, S. R. (2017). High-Frequency Sequences in the Quaternary of Pelotas Basin (coastal plain): a record of degradational stacking as a function of longer-term base-level fall. Braz. J. Geol. 47, 183-207. doi: 10.1590/2317-4889201720160138

Velasco, G., Reis, E. G., and Vieira, J. P. (2007). Calculating growth parameters of Genidens barbus (Siluriformes, Ariidae) using length composition and age data. J. Appl. Ichthyol. 23, 64-69. doi: 10.1111/j.1439-0426.2006.00793.x

Vieira, J. P. (1991). Juvenile mullets (Pisces: Mugilidae) in the estuary of Lagoa dos Patos. RS, Brazil. Copeia 1991, 409-418. doi: 10.2307/1446590

Vieira, J. P., and Castello, J. (1997). "Fish fauna," in Subtropical Convergence Environments, the Coast and Sea in the Southwestern Atlantic, eds U. Seeliger, C. Odebrecht, and P. P. Castello (Berlin: Springer), 56-61.

Vieira, J. P., and Scalabrin, C. (1991). Migração reprodutiva da Tainha (Mugil platanus, Günther, 1880) no sul do Brasil. Atlântica 13, 131-141.

Whitehead, P. J. P., Nelson, G. J., and Wongratana, T. (1988). Clupeoid Fishes of the World (Suborder Clupeoidei): An annotated and Illustrated Catalogue of the Herrings, Sardines, Pilchards, Sprats, Shads, Anchovies and Wolf-Herrings. Rome: FAO Fish Synopsis.

Conflict of Interest Statement: The authors declare that the research was conducted in the absence of any commercial or financial relationships that could be construed as a potential conflict of interest.

Copyright (c) 2019 Fontoura, Schulz, Alves, Silveira, Pereira and Antonetti. This is an open-access article distributed under the terms of the Creative Commons Attribution License (CC BY). The use, distribution or reproduction in other forums is permitted, provided the original author(s) and the copyright owner(s) are credited and that the original publication in this journal is cited, in accordance with accepted academic practice. No use, distribution or reproduction is permitted which does not comply with these terms. 